\title{
Spatial dynamics of virus-like particles and heterotrophic bacteria within a shallow coral reef system
}

\author{
Justin R. Seymour ${ }^{1, *}$, Nicole Patten ${ }^{1}$, David G. Bourne ${ }^{2}$, James G. Mitchell ${ }^{1,3}$ \\ ${ }^{1}$ Biological Sciences, Flinders University, PO Box 2100, Adelaide, South Australia 5001, Australia \\ ${ }^{2}$ Australian Institute of Marine Science, PMB No. 3, Cape Ferguson, Townsville, Queensland 4810, Australia \\ ${ }^{3}$ Marine Microbiology, Ocean Research Institute, University of Tokyo, 1-15-1 Minamidai, Nakano-ku, Tokyo 164-8639, Japan
}

\begin{abstract}
Variations in the abundance and community characteristics of virus-like particles (VLP) and heterotrophic bacteria within a shallow, near-shore coral reef were determined using flow cytometric analysis. Mean concentrations of $6.5 \times 10^{5}$ and $1.3 \times 10^{5} \mathrm{ml}^{-1}$ were observed for VLP and bacterioplankton, respectively, although concentrations of both populations varied significantly $(\mathrm{p}<$ $0.05)$ between 4 distinct reef water types. Significant $(p<0.05)$ variability in the percentage of high DNA (HDNA) bacteria, applied here as an estimate of the proportion of active bacterial cells, and the virus:bacteria ratio (VBR) was also observed between different reef water types. Microscale profiles were taken in the $12 \mathrm{~cm}$ layer of water directly above the surface of coral colonies to determine the small-scale spatial relationships between coral colonies and planktonic microbial communities. Across these profiles, mean changes of 2- and 3.5-fold were observed for bacterioplankton and VLP communities, respectively, with VLP abundance positively correlated to bacteria in $75 \%$ of profiles. Bacterial and VLP abundance, percentage of HDNA bacteria, and VBR all generally exhibited increasing trends with proximity to the coral surface. VLP abundance was significantly higher $(\mathrm{p}<$ 0.05 ) in the $4 \mathrm{~cm}$ closest to the coral surface, and the VBR was higher at the coral surface than in any other zone. The patterns observed here indicate that VLP represent an abundant and dynamic community within coral reefs, are apparently coupled to the spatial dynamics of the bacterioplankton community, and may consequently significantly influence nutrient cycling rates and food-web structure within coral reef ecosystems.
\end{abstract}

KEY WORDS: Coral reefs · Virus-like particles · Bacterioplankton

\section{INTRODUCTION}

Coral reefs support rich, diverse and active communities of free-living and epibiotic bacteria (Moriarty et al. 1985, Paul et al. 1986, Hoppe et al. 1988, Rohwer et al. 2002), which are important components in nutrient cycling processes (Ferrier-Pages et al. 1998), and can represent a trophic resource for some coral species (Sorokin 1973, Bak et al. 1998). Alternatively, certain bacteria are coral pathogens, and have been attributed to disease outbreaks (Richardson 1998, Ben-Haim \& Rosenberg 2002, Patterson et al. 2002) and coral bleaching (Kushmaro et al. 1996, 1997).

While the ecological importance of bacteria in coral reef systems is now unequivocal, the role of viruses in these ecosystems has, to our knowledge, yet to be addressed. Viruses are the numerically dominant organisms in the ocean, and viral infection is a major structuring agent in the dynamics of marine microbial communities (Fuhrman 1999). Viral lysis of autotrophic and heterotrophic microorganisms influences rates of nutrient cycling through microbial food webs (Proctor \& Fuhrman 1990, Fuhrman 1999), and could conse- 
quently alter the extent of coupling between coral reefs and associated microbial communities. Viruses are also pathogens of larger organisms, and while they have not yet been shown to infect corals, viruses have been observed in the cells of other cnidarians (Wilson \& Chapman 2001) and were recently shown to infect zooxanthellae (Wilson et al. 2001), the symbiotic dinoflagellates essential for coral growth and reproduction (Muscatine 1990). Consequently, the role of viruses in coral disease and bleaching events could also be important (Wilson et al. 2001).

Before the influence of viruses in coral reef systems can be elucidated, an understanding of the dynamics of viral populations associated with coral reefs is required. Variability amongst coral reef bacterial communities has been investigated at a variety of spatial and temporal scales (Moriarty 1979, Moriarty et al. 1985, Paul et al. 1986, Hoppe et al. 1988, Gast et al. 1998), and important small-scale shifts in abundance, activity, and composition have been observed (Paul et al. 1986, Gast et al. 1998, van Duyl \& Gast 2001, FriasLopez et al. 2002, Rohwer et al. 2002). In other aquatic environments, viral populations exhibit microscale variability that often mirrors bacterial distributions (Hewson et al. 2001, Middelboe et al. 2003). To investigate the potential role of viruses in coral reef ecosystems, we have measured the microscale distribution patterns of virus-like particles (VLP) and heterotrophic bacteria within a shallow coastal coral reef.

\section{MATERIALS AND METHODS}

Study site and sampling strategy. Sampling was conducted during July 2003 at Nelly Bay $\left(146^{\circ} 51^{\prime} \mathrm{E}\right.$, $19^{\circ} 09^{\prime} \mathrm{S}$ ) on Magnetic Island, approximately $8 \mathrm{~km}$ from the mainland of northeastern Australia and within the Great Barrier Reef Marine Park (Fig. 1). Nelly Bay is a large southeasterly facing embayment, bounded by a fringing coral reef situated approximately $50 \mathrm{~m}$ offshore. In this study, microbial communities associated with different features of the Nelly Bay reef were compared by sampling 4 discrete reef water types: (1) surface-water: samples were collected from the surface (5 $\mathrm{cm}$ depth) of the water column overlaying the coral reef; (2) coral-water: samples were collected from the $12 \mathrm{~cm}$ vertical layer of water immediately above the surface of coral colonies; (3) lagoon: samples were collected from mid-water (approximately $1 \mathrm{~m}$ depth) in the lagoon situated on the shoreward side of the coral reef, and; (4) sediment-water: samples were collected from the $12 \mathrm{~cm}$ vertical layer of water directly above the sandy sediment in the lagoon adjacent to the coral reef, where the water depth was $1.5 \mathrm{~m}$.

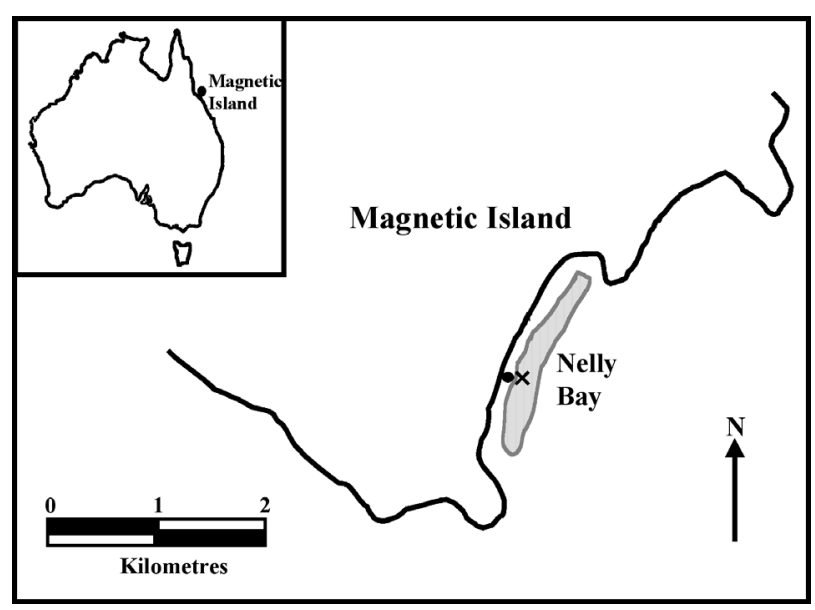

Fig. 1. Nelly Bay sampling location. •: approximate point of sampling in the lagoon on the shoreward side of the reef where the sediment-water and lagoon samples were obtained. $x$ : approximate location of the $15 \mathrm{~m}$ sampling transect from where coral-water and surface-water samples were obtained at $5 \mathrm{~m}$ intervals

Coral-water samples were collected at $5 \mathrm{~m}$ intervals along a $15 \mathrm{~m}$ transect on the shoreward boundary of the Nelly Bay reef, in water of approximately $1 \mathrm{~m}$ depth, and at each point surface-water samples were also collected. Duplicate lagoon and sediment-water samples were collected from the lagoon approximately $10 \mathrm{~m}$ to the shoreward side of the reef (Fig. 1). Surfacewater samples were collected with sterile Schott bottles, while samples from all other reef water types were obtained using a hand-operated microscale sampling device consisting of a linear array of sterile $1 \mathrm{ml}$ syringes, each separated by a distance of $10 \mathrm{~mm}$. This device incorporated a lever-action design and allowed 12 individual $800 \mu \mathrm{l}$ samples to be collected simultaneously, and was primarily designed to characterise the microscale vertical distributions of VLP and heterotrophic bacteria in the water directly above coral surfaces. Using this device, microscale vertical profiles were taken from immediately above $(1$ to $12 \mathrm{~cm})$ the surface of live colonies of the coral species Acropora millepora. We also used this device to take duplicate profiles of VLP and bacterial communities in lagoon and sediment-water samples to compare microscale distribution patterns observed in these environments to those associated with coral surfaces. After collection, all samples were fixed with paraformaldehyde $(1 \%$ final concentration), frozen in liquid nitrogen and stored at $-80^{\circ} \mathrm{C}$.

Sample analysis. Concentrations of VLP and heterotrophic bacteria were determined using flow cytometric analysis (Marie et al. 1999a), which was conducted 
within 1 mo of sample collection. Samples were diluted 1:6 in TE buffer (10 mM Tris, 1 mM EDTA; $\mathrm{pH} 7.5)$, stained with SYBR-I Green solution (5:100 000 dilution; Molecular Probes), and incubated in the dark for 15 min (Marie et al. 1999a,b). Flow cytometric analysis was conducted using a Becton-Dickinson FACScan flow cytometer, with phosphate-buffered saline (PBS) solution employed as sheath fluid, and the discriminator set to green fluorescence. All measured flow cytometric parameters were normalised to concentrations and fluorescence of $1 \mu \mathrm{m}$ diameter fluorescent beads (Molecular Probes). Data for individual sub-samples were collected in list-mode files, and populations of bacteria and VLP were identified using Win Midi 2.8 ( ${ }^{\oplus}$ Joseph Trotter) flow cytometry analysis software.

Populations of heterotrophic bacteria were distinguished according to cell side scatter (indicative of cell size) and SYBR Green fluorescence (indicative of nucleic acid content) parameters (Marie et al. 1997). The bacterial population was further divided into high DNA (HDNA) and low DNA (LDNA) categories according to variations in green fluorescence (Li et al. 1995, Gasol et al. 1999) (Fig. 2A), and the percentage of HDNA cells was then applied as a measure of the active proportion of cells within the bacterial community (Jellett et al. 1996, Gasol et al. 1999, Lebaron et al. 2001).

A population of VLP, similar to populations previously identified using flow cytometry (Marie et al. 1999a,b, Brussard et al. 2000, Chen et al. 2001) was defined here as a population of fluorescent particles clearly above background noise levels, but with much lower fluorescence than the bacterial population (Fig. 2B,C). Other studies have differentiated 2 to 4 virus-like populations in natural aquatic samples using flow cytometry (Marie et al. 1999a,b, Chen et al. 2001). Such a clear differentiation, however, was not always evident here, so the VLP were enumerated as a single population.

Concentrations and distributions of bacteria and VLP were measured and compared between the 4 reef water types and within microscale vertical profiles. To obtain a broad representation of the patterns occurring in the water immediately above the coral surfaces and to minimise the influence of any variability between the individual profiles, data from all coral surface profiles were combined and then binned into $4 \mathrm{~cm}$ depth regions. All data were tested for normality and homoscedasticity, and 1-way analysis of variance (ANOVA) and Tukey tests were then applied to determine whether significant differences in the bacterial and VLP communities occurred between the different depth regions within the microscale profiles, and between the different water types (Zar 1984). All statistical analyses were performed using SPSS Version 11.0 .
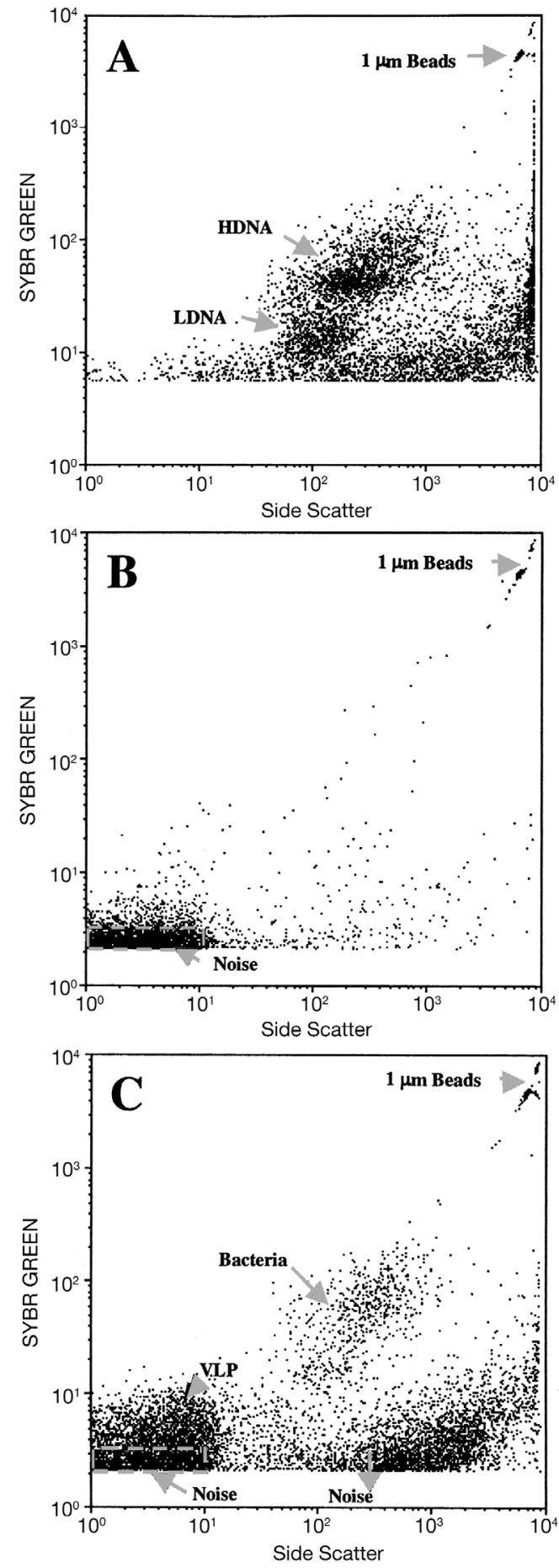

Fig. 2. Characteristic cytograms illustrating the populations identified in the Nelly Bay samples. (A) Bacterial populations in an undiluted sample, with virus-sized particles excluded from analysis. Two sub-populations representing high (HDNA) and low (LDNA) groups are evident. (B) $0.02 \mu \mathrm{m}$ filtered seawater was stained with SYBR Green (5:100 000 dilution) to determine the limit of background noise detection in the flow cytometric analysis. (C) Virus-like particles (VLP) were discriminated as the population above background noise levels, but with lower green fluorescence than the bacterial population in samples diluted 1:6 in TE buffer (Marie et al. 1999a) 


\section{RESULTS AND DISCUSSION}

\section{Bulk patterns}

Mean concentrations of VLP and bacteria varied significantly according to location on the reef $(p<0.01)$. Concentrations of heterotrophic bacteria were significantly higher $(p<0.01)$ in the lagoon (mean: $1.8 \times$ $10^{5} \mathrm{ml}^{-1}$ ) than at any other site (Fig. 3B). The incidence of higher bacterioplankton concentrations in the waters adjacent to coral reefs, rather than directly over the reefs, has been observed previously (Moriarty 1979, Moriarty et al. 1985, Linley \& Koop 1986, Ayukai 1995, Torreton \& Dufour 1996), and may be explained by the removal of bacterial biomass by benthic filterfeeding organisms associated with reefs (Ayukai 1995, Gast et al. 1998). Alternatively, levels of bacterial productivity and activity are generally higher above coral reefs than in the surrounding waters (Moriarty et al. 1985, Hoppe et al. 1988, van Duyl \& Gast 2001) due to the high concentrations of dissolved and particulate organic matter that is released into overlaying reef waters by corals (Ducklow \& Mitchell 1979, Herndl \& Velimirov 1986, Ferrier-Pages et al. 1998, van Duyl \& Gast 2001), and benthic algae (Schramm et al. 1984, Ducklow 1990). We found, however, that levels of HDNA bacteria in the coral-water samples were significantly lower $(p<0.001)$ than at any other site sampled (Fig. 3C). A potential mechanism for this pattern may be the selective consumption of the larger HDNA bacteria (Gasol et al. 1999) by benthic filter-feeding organisms on the reef (Reiswig 1971, Sorokin 1973, Wilkinson et al. 1984, Witte et al. 1997).

Abundances of VLP were significantly correlated to bacterial abundance in all samples and environments (mean $\mathrm{r}=0.83, \mathrm{p}<0.05, \mathrm{n}=12$ ), but to the percentage of HDNA bacteria in only $33 \%$ of cases. Like the heterotrophic bacteria, highest concentrations of VLP were observed in the lagoon, where mean concentrations were $8.5 \times 10^{5} \mathrm{ml}^{-1}$ (Fig. 3A). Concentrations of VLP were significantly higher $(p<0.05)$ in the lagoon than in the surface-water and the sediment-water, possibly due to UV inactivation of viruses in the surfacewater samples (Suttle \& Chen 1992, Wilhelm et al. 1998) and adsorption to the sediments and suspended particles in the sediment-water samples (Sakoda et al. 1997). However, unlike the bacterial community, VLP concentrations in the lagoon were not significantly higher than in the waters directly over the coral reef. Indeed, mean VLP concentrations in 2 profiles taken from above the coral exceeded levels observed in the lagoon and the virus:bacteria ratio (VBR) was consequently significantly higher $(p<0.01)$ over the coral reef than at any other site (Fig. 3D). Changes in the VBR of this type may suggest a potential de-coupling
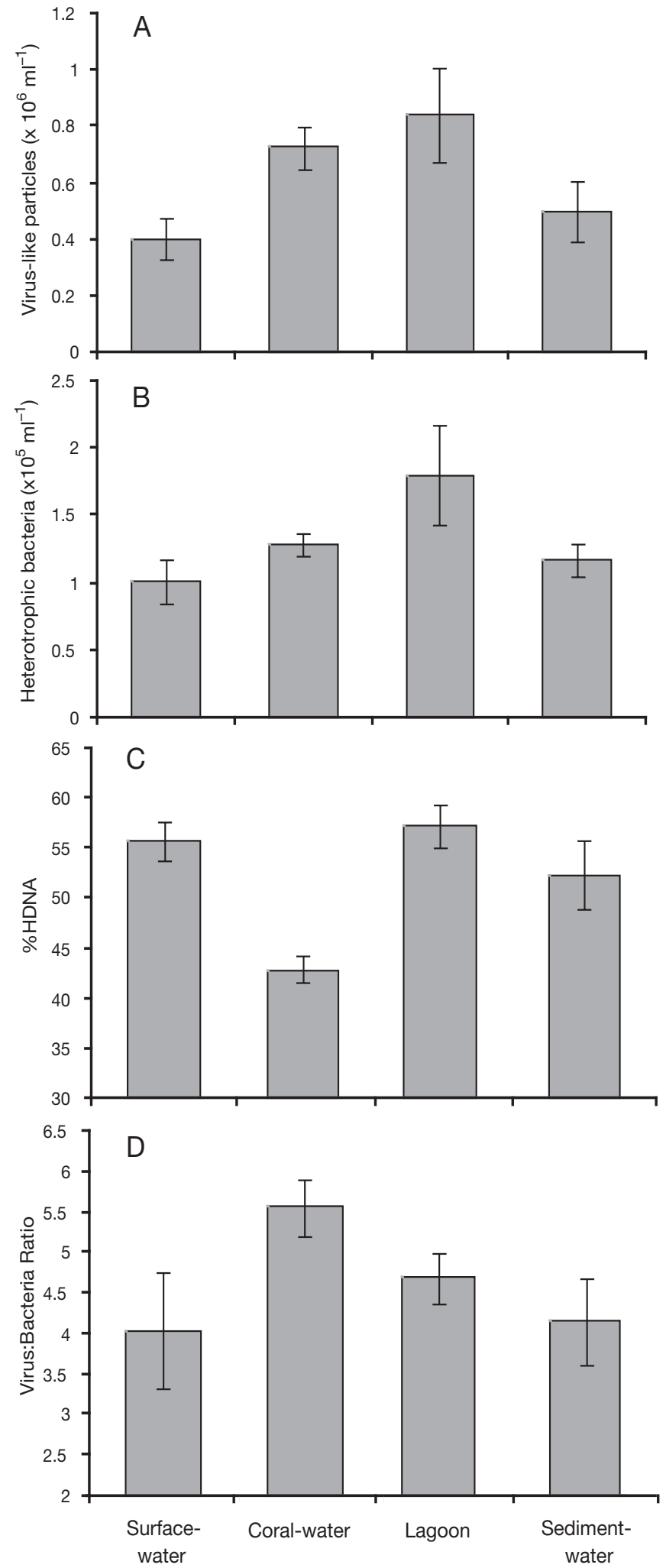

Fig. 3. Comparisons of the (A) virus-like particle abundance, (B) heterotrophic bacterial abundance, (C) percentage of HDNA bacteria, and (D) virus:bacteria ratio between the 4 reef zones studied around the Nelly Bay Reef 
of bacterial and viral communities or a shift in virus production and loss rates within coral reef waters (Wommack \& Colwell 2000).

\section{Microscale distributions}

Microscale measurements allow for a more direct examination of associations between coral colonies and adjacent microbial communities than can be achieved by bulk water sampling. We observed clear gradients in the abundance of both bacteria and VLP within the $12 \mathrm{~cm}$ of water directly overlaying the surface of coral colonies (Fig. 4A,B). Mean changes in the abundance of bacteria and VLP of 2- and 3.5-fold, respectively, were observed across profiles, and bacterial and VLP concentrations exhibited increasing trends towards coral surfaces in 3 out of 4 profiles. Despite mean levels of HDNA cells being lower in the coral-water samples than in any other reef zone (Fig. 3C), the proportion of these cells also increased with proximity to coral surfaces in all coral-water microscale profiles (Fig. 4D). Conversely, when microscale profiles were taken from above the sediment surface and in the lagoon, no clear distributional trends were evident in profiles, and the degree of vari- ability across these profiles was generally less than within the coral surface profiles (data not shown). This implies that direct associations between communities of VLP and bacteria with the surfaces of coral colonies are important in the generation of the heterogeneities observed here.

Generally, the highest concentrations of VLP, total bacteria, and HDNA bacteria were observed within the $4 \mathrm{~cm}$ closest to the coral surface (Fig. 4). When data were combined from all profiles, and binned into $4 \mathrm{~cm}$ depth regions, average VLP abundance was found to be significantly higher $(p<0.05)$ in the $4 \mathrm{~cm}$ layer closest to the coral surface (Fig. 5A). ANOVA suggested that heterotrophic bacterial abundance and the percentage of HDNA bacteria also varied significantly $(\mathrm{p}<$ 0.05 ) with distance from the coral surface (Fig. 5B,C), but post-hoc Tukey tests revealed that only the 0 to 4 and 8 to $12 \mathrm{~cm}$ layers differed significantly $(\mathrm{p}<0.05)$ from one another. Furthermore, in 3 out of 4 profiles, a least-squared regression analysis of the raw data revealed a statistically significant $\left(\mathrm{r}^{2}>0.47, \mathrm{p}<0.01\right)$ trend of increasing bacterial abundance towards the coral surface, indicative of a gradient in bacterial abundance within this $12 \mathrm{~cm}$ layer, rather than the sharp boundary expected to occur at the coral surface interface (Paul et al. 1986). These gradients in bacterial
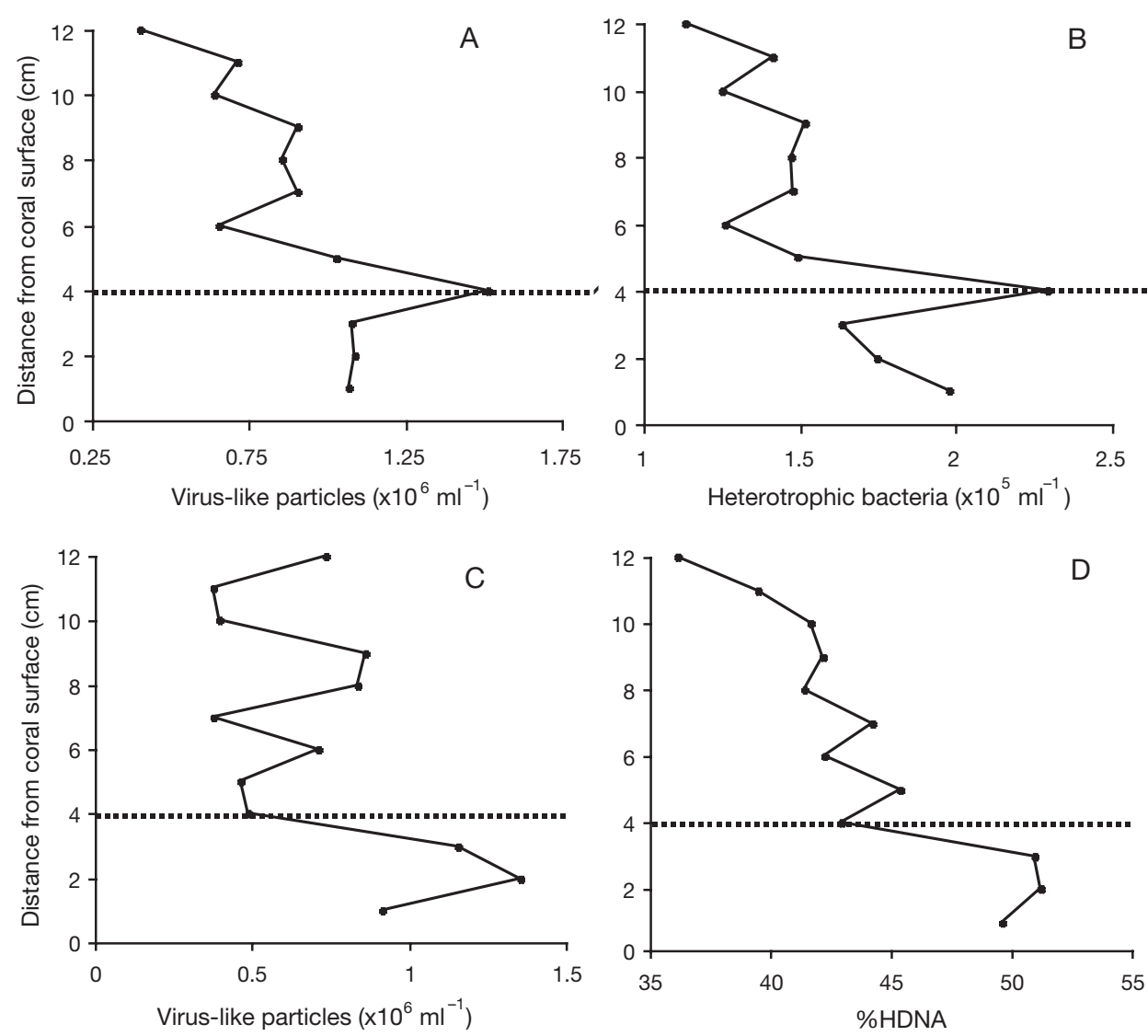

Fig. 4. Examples of 2 microscale depth profiles from the $12 \mathrm{~cm}$ directly above coral surfaces. (A) VLP and (B) bacterial abundances from Profile 1. (C) VLP abundance and (D) the relative percentage of HDNA from Profile 2, respectively. Horizontal line respresents the $4 \mathrm{~cm}$ depth region closest to the coral surface where VLP and bacterial abundances were generally elevated above background levels 

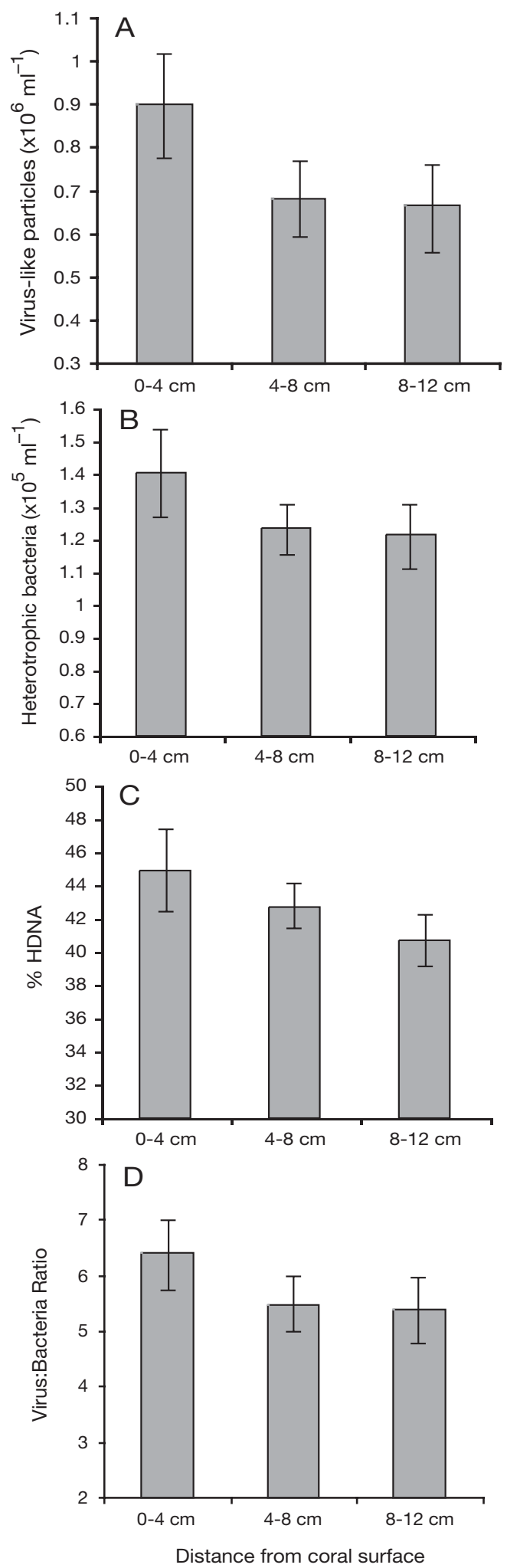

Fig. 5. Data from all 4 microscale profiles taken adjacent to coral surfaces were combined and pooled into $4 \mathrm{~cm}$ depth categories relative to distances from coral surfaces. Columns represent mean data for respective depth categories. Error bars represent $95 \% \mathrm{CI}$ abundance may have been generated by either freeliving bacterioplankton responding to the flux of dissolved and particulate organic matter from coral surfaces (Ducklow 1990, Ferrier-Pages et al. 1998), or the loss of organisms away from the coral surface layer where microbial abundances and activities are much higher than in the water column (Paul et al. 1986). The microscale shifts in the abundance of VLP observed here may have occurred either in direct response to the changes in the abundance and activity of the bacterial community, or perhaps in association with the coral itself. Turbulent flow around coral colonies may also have a profound effect on the distributions of matter and planktonic organisms above coral surfaces (Gast et al. 1998), but specific measurements of turbulence and shear rates in the Nelly Bay reef were not made during this study.

In most aquatic environments, viral abundance is closely correlated to bacterial biomass (Boehme et al. 1993, Cochlan et al. 1993, Drake et al. 1998, Middelboe et al. 2003) and activity (Heldal \& Bratbak 1991, Middelboe et al. 2003). In this study, VLP distributions were significantly correlated to bacteria in all microscale profiles (mean $\mathrm{r}=0.81, \mathrm{p}<0.05$ ), but to bacterial activity (percentage of HDNA bacteria) in only 1 out of 4 samples. Within microscale profiles, we found that the VBR was generally highest in the $4 \mathrm{~cm}$ closest to the coral surface (Fig. 5D). This is consistent with the prediction that increases in VBR are likely to occur in environments (or microenvironments) favouring fast bacterial growth and high productivity (Wommack \& Colwell 2000). However, it is interesting to note that when comparing the different reef water types, the coral surface water samples exhibited the highest VBR but the lowest mean proportion of HDNA cells. In this instance, the VBR was high in an environment where the mean bacterial activity was lowest. The reason for this discrepancy is not clear, but the VBR has also been related to other factors including relative bacterial abundance or host community diversity (Wommack \& Colwell 2000), and these parameters have been shown to vary significantly between coral-associated communities and water column communities of bacteria (Paul et al. 1986, Rohwer et al. 2002). Therefore, the shifts in the VBR observed here could be indicative of fundamental shifts in the ecology or composition of the VLP and bacterial communities and the subsequent virushost interactions occurring close to coral surfaces.

The shifts in the abundance of the VLP community and changes in the VBR observed in this study imply that viruses are an apparently dynamic and potentially ecologically relevant element within coral reef ecosystems. Viral lysis of bacterioplankton populations may profoundly alter rates of nutrient regeneration and organic matter cycling processes within coral reef sys- 
tems, as well as influencing food availability for coral reef benthic filter feeders.

Viruses may also influence coral reef communities by infecting larger coral reef organisms, including coral colonies. Microbial pathogens have been attributed to coral diseases (Richardson 1998, Cooney et al. 2002, Patterson et al. 2002, Pantos et al. 2003) and coral bleaching events (Kushmaro et al. 1996, 1997). However, the etiology of several common and severe coral diseases has not been characterised (Richardson 1998), and while not yet demonstrated, viral infection indeed remains a possible vector for the spread of coral diseases and could also contribute to bleaching events on coral reefs (Wilson et al. 2001). Our results indicate that VLP can represent an abundant and dynamic community within coral reefs, and in light of escalating concerns regarding the widespread decline of the world's coral reefs (Hoegh-Guldberg 1999, Buddemeier 2001, Knowlton 2001, Gardner et al. 2003), it would be imprudent to neglect the potential importance of viruses within these systems.

Acknowledgements. We are grateful to D. Edyvean for constructing the microscale sampling device, and to S. Bailey from the Flow Cytometry Unit of the Flinders Medical Centre for providing technical support in flow cytometry. Constructive comments and suggestions were provided by 4 anonymous referees. Funding for the research was provided by the Australian Research Council and the Flinders University School of Biological Sciences.

\section{LITERATURE CITED}

Ayukai T (1995) Retention of phytoplankton and planktonic microbes on coral reefs within the Great barrier Reef, Australia. Coral Reefs 14:141-147

Bak RPM, Joenje M, de Jong I, Lambrechts DYM, Nieuwland G (1998) Bacterial suspension feeding by coral benthic organisms. Mar Ecol Prog Ser 175:285-288

Ben-Haim Y, Rosenberg E (2002) A novel Vibrio sp. pathogen of the coral Pocilliopora damicornis. Mar Biol 141:47-55

Boehme J, Frischer ME, Jiang SC, Kellogg CA, Pichard S, Rose JB, Steinway C, Paul JH (1993) Viruses, bacterioplankton and phytoplankton in the southeastern Gulf of Mexico: distribution and contribution to oceanic DNA pools. Mar Ecol Prog Ser 97:1-10

Brussaard CPD, Marie D, Bratbak G (2000) Flow cytometric detection of viruses. J Virol Meth 85:175-182

Buddemeier RW (2001) Is it time to give up? Bull Mar Sci 69: 317-326

Chen F, Lu JR, Binder BJ, Liu YC, Hodson RE (2001) Application of digital image analysis and flow cytometry to enumerate marine viruses stained with SYBR Gold. Appl Environ Microbiol 67:539-545

Cochlan WP, Wikner J, Steward GF, Smith DC, Azam F (1993) Spatial distribution of viruses, bacteria and chlorophyll a in neritic, oceanic and estuarine environments. Mar Ecol Prog Ser 92:77-87

Cooney RP, Pantos O, Le Tissier MDA, Barer MR, O'Donnell AGO, Bythell JC (2002) Characterization of the bacterial consortium associated with black band disease in coral using molecular microbiological techniques. Environ Microbiol 4:401-413

Drake LA, Choi KH, Haskell AGE, Dobbs FC (1998) Vertical profiles of virus-like particles and bacteria in the water column and sediments of Chesapeake Bay, USA. Aquat Microb Ecol 16:17-25

Ducklow HW (1990) The biomass, production and fate of bacteria in coral reefs. In: Dubinsky Z (ed) Coral reefs. Elsevier, Amsterdam, p 265-290

Ducklow HW, Mitchell R (1979) Bacterial populations and adaptations in the mucus layers on living corals. Limnol Oceanogr 24:715-725

Ferrier-Pages C, Gattuso JP, Cauwet G, Jaubert J, Allemand $D$ (1998) Release of dissolved organic carbon and nitrogen by the zooxanthellate coral Galaxa fascicularis. Mar Ecol Prog Ser 172:265-274

Frias-Lopez J, Zerkle AL, Bonheyo GT, Fouke BW (2002) Partitioning of bacterial communities between seawater and healthy, black band diseased, and dead coral surfaces. Appl Environ Microb 68:2214-2228

Fuhrman JA (1999) Marine viruses and their biogeochemical and ecological effects. Nature 399:541-547

Gardner TA, Cote IM, Gill JA, Grant A, Watkinson AR (2003) Long-term region-wide declines in Caribbean corals. Science 301:958-960

Gasol JM, Zweifel UL, Peters F, Fuhrman JA, Hagström ^ (1999) Significance of size and nucleic acid content heterogeneity as measured by flow cytometry in natural planktonic bacteria. Appl Environ Microbiol 65: 4475-4483

Gast GJ, Wiegman S, Wieringa E, van Duyl FC, Bak RPM (1998) Bacteria in coral reef water types: removal of cells, stimulation of growth and mineralization. Mar Ecol Prog Ser 167:37-45

Heldal M, Bratbak G (1991) Production and decay of viruses in aquatic environments. Mar Ecol Prog Ser 72:205-212

Herndl GJ, Velimirov B (1986) Microheterotrophic utilization of mucus released by the Mediterranean coral Cladocora cespitosa. Mar Biol 90:363-369

Hewson I, O'Neil JM, Fuhrman JA, Dennison WC (2001) Virus-like particle distribution and abundance in sediments and overlying waters along eutrophication gradients in two subtropical estuaries. Limnol Oceanogr 46: $1734-1746$

Hoegh-Guldberg O (1999) Coral bleaching, climate change and the future of the worlds coral reefs. Mar Freshw Res 50:839-866

Hoppe HG, Schramm W, Bacold P (1988) Spatial and temporal distribution of pelagic microorganisms and their proteolytic activity over a partly destroyed coral reef. Mar Ecol Prog Ser 44:95-102

Jellett JF, Li WKW, Dickie PM, Boraie A, Kepkay PE (1996) Metabolic activity of bacterioplankton communities assessed by flow cytometry and single carbon substrate utilisation. Mar Ecol Prog Ser 136:213-225

Knowlton N (2001) The future of coral reefs. Proc Natl Acad Sci USA 98:5419-5425

Kushmaro A, Loya Y, Fine M, Rosenberg E (1996) Bacterial infection and coral bleaching. Nature 380:396

Kushmaro A, Rosenberg E, Fine M, Loya Y (1997) Bleaching of the coral Oculina patagonica by VibrioAK-1. Mar Ecol Prog Ser 147:159-165

Lebaron P, Servais P, Agogue H, Courties C, Joux F (2001) Does the high nucleic acid content of individual bacterial cells allow us to discriminate between active cells and inactive cells in aquatic systems? Appl Environ Microbiol $67: 1775-1782$ 
Li WKW, Jellett JF, Dickie PM (1995) DNA distributions in planktonic bacteria stained with TOTO or TO-Pro. Limnol Oceanogr 40:1485-1495

Linley EAS, Koop K (1986) Significance of pelagic bacteria as a trophic resource in a coral reef lagoon, One Tree Island, Great Barrier Reef. Mar Biol 92:457-464

Marie D, Partensky F, Jacquet S, Vaulot D (1997) Enumeration and cell cycle analysis of natural populations of marine picoplankton by flow cytometry using a novel nucleic acid dye. Appl Environ Microbiol 63:186-193

Marie D, Brussard CPD, Thyraug R, Bratbak G, Vaulot D (1999a) Enumeration of marine viruses in culture and natural samples by flow cytometry. Appl Environ Microbiol 65:45-52

Marie D, Partensky F, Vaulot D, Brussaard C (1999b) Enumeration of phytoplankton, bacteria, and viruses in marine samples. Curr Prot Cytom 11.11.1-11.11.15

Middelboe M, Glud RN, Finster K (2003) Distribution of viruses and bacteria in relation to diagenetic activity in an estuarine sediment. Limnol Oceanogr 48:1447-1456

Moriarty DJW (1979) Biomass of suspended bacteria over coral reefs. Mar Biol 53:193-200

Moriarty DJW, Pollard PC, Hunt WG (1985) Temporal and spatial variation in bacterial production in the water column over a coral reef. Mar Biol 85:285-292

Muscatine L (1990) The role of symbiotic algae in carbon and energy flux in reef corals. In: Zubinsky Z (ed) Coral reefs. Elsevier, Amsterdam, p 75-87

Pantos O, Cooney RP, Le Tissier MDA, Barer MR, O'Donnell AG, Bythell JC (2003) The bacterial ecology of a plaguelike disease affecting the Caribbean coral Montstrea annularis. Environ Microbiol 5:370-382

Patterson KL, Porter JW, Ritchie KB, Polson SW, Mueller E, Peters EC, Santavy DL, Smith GW (2002) The etiology of white pox, a lethal disease of the Caribbean elkhorn coral, Acropora palmata. Proc Natl Acad Sci USA 99:8725-8730

Paul JH, DeFlaun MF, Jeffrey WH (1986) Elevated levels of microbial activity in the coral surface microlayer. Mar Ecol Prog Ser 33:29-40

Proctor LM, Fuhrman JA (1990) Viral mortality of marine bacteria and cyanobacteria. Nature 343:60-62

Reiswig HM (1971) Particle feeding in natural populations of three marine demosponges. Biol Bull (Woods Hole) 141: $569-591$

Editorial responsibility: Otto Kinne (Editor-in-Chief), Oldendorf/Luhe, Germany
Richardson LL (1998) Coral diseases: what is really known? TREE 13:438-443

Rohwer F, Seguritan V, Azam F, Knowlton N (2002) Diversity and distribution of coral associated bacteria. Mar Ecol Prog Ser 243:1-10

Sakoda A, Sakai Y, Hayakawa K, Suzuki M (1997) Adsorption of viruses in water environment onto solid surfaces. Water Sci Technol 35:107-114

Schramm W, Gualberto E, Orosco C (1984) Release of dissolved organic matter from marine tropical reef plants: temperature and desiccation effects. Bot Mar 27:71-77

Sorokin YI (1973) On the feeding of some scleractinian corals with bacteria and dissolved organic matter. Limnol Oceanogr 18:380-385

Suttle CA, Chen F (1992) Mechanisms and rates of decay of marine viruses in seawater. Appl Environ Microbiol 58: 3721-3729

Torreton JP, Dufour P (1996) Temporal and spatial stability of bacterioplankton biomass and productivity in an atoll lagoon. Aquat Microb Ecol 11:251-261

van Duyl FC, Gast GJ (2001) Linkage of small-scale spatial variations in DOC, inorganic nutrients and bacterioplankton growth with different coral reef water types. Aquat Microb Ecol 24:17-26

Wilhelm SW, Weinbauer MG, Suttle CA, Jeffrey WH (1998) The role of sunlight in the removal and repair of viruses in the sea. Limnol Oceanogr 43:586-592

Wilkinson CR, Garrone R, Vacelet J (1984) Marine sponges discriminate between food bacteria and bacterial symbionts:electron microscopy, autoradiography, and in situ evidence. Proc R Soc Lond 220:519-528

Wilson WH, Chapman DM (2001) Observations of virus-like particles in thin sections of the plumrose anemone, Metridium senile. J Mar Biol Assoc UK 81:879-880

Wilson WH, Francis I, Ryan K, Davy SK (2001) Temperature induction of viruses in symbiotic dinoflagellates. Aquat Microb Ecol 25:99-102

Witte U, Brattegard T, Graf G, Springer B (1997) Particle capture and deposition by deep sea sponges from the Norwegian-Greenland Sea. Mar Ecol Prog Ser 154:241-252

Wommack KE, Colwell RA (2000) Virioplankton: viruses in aquatic ecosystems. Microbiol Molec Biol Rev 64:69-114

Zar JH (1984) Biostatistical analysis, 2nd edn. Prentice Hall, Englewood Cliffs, NJ

Submitted: November 12, 2003; Accepted: August 31, 2004 Proofs received from author(s): February 24, 2005 